\author{
Samir Kumar Sadhu · Panadda Phattanawasin \\ M. Shahabuddin Kabin Choudhuri · Takashi Ohtsuki \\ Masami Ishibashi
}

\title{
A new lignan from Aphanamixis polystachya
}

Received: 13 February 2006/ Accepted: 20 March 2006/Published online: 17 May 2006

(C) The Japanese Society of Pharmacognosy and Springer-Verlag 2006

\begin{abstract}
A new lignan, polystachyol (1), two lignan glycosides, lyoniside (2) and nudiposide (3), and a sterol, ergosta-4,6,8(14),22-tetraen-3-one (4), with stigmasterol, and oleic and linoleic acids, have been isolated from an $\mathrm{MeOH}$ extract of the dried bark of Aphanamixis polystachya. The structures of the isolated compounds were elucidated by analysis of $1 \mathrm{D}$ and 2D NMR and mass spectroscopic data. The compounds did not have growth inhibitory activity against HeLa cells.
\end{abstract}

Keywords Aphanamixis polystachya $\cdot$ Meliaceae Polystachyol $\cdot$ Lignan $\cdot$ Sterol $\cdot$ Cell growth inhibitory activity

\section{Introduction}

Aphanamixis polystachya (Wall.) Parker or Amoora rohituka (family: Meliaceae; local names: Roina, Pitraj, etc.) is a medicinal plant of Bangladesh. The bark is astringent, and is used to treat spleen and liver diseases, tumors, and abdominal complaints. Different types of compound, for example limonoids, terpenoids,

S.K. Sadhu · T. Ohtsuki · M. Ishibashi $(\square)$

Graduate School of Pharmaceutical Sciences, Chiba University, 1-33 Yayoi-cho, Inage-ku, Chiba 263-8522, Japan

E-mail: mish@chiba-u.ac.jp

Tel.: + 81-43-2902913

Fax: + 81-43-2902913

S.K. Sadhu

Pharmacy Discipline, Life Science School, Khulna University, Khulna 9208, Bangladesh

P. Phattanawasin

Faculty of Pharmacy, Silpakorn University, Nakorn Pathom, 73000, Thailand

M.S.K. Choudhuri

Department of Pharmacy, Faculty of Biological Science,

Jahangirnagar University, Savar, Dhaka, Bangladesh glycosides, an alkaloid, and a saponin have previously been isolated from this plant [1]. With the objective of isolating components bioactive against tumors, an $\mathrm{MeOH}$ extract of the dried bark was checked for growth inhibitory activity against HeLa cells and shown to have potent activity with an $\mathrm{IC}_{50}$ of approximately $50 \mu \mathrm{g} \mathrm{mL}^{-1}$. The extract was then partitioned successively between $n$-hexane, EtOAc and $n$ - $\mathrm{BuOH}$, and water. Of these, the $n$-BuOH and $n$-hexane extracts were potent active fractions with $\mathrm{IC}_{50}$ of approximately $22 \mu \mathrm{g} \mathrm{mL}^{-1}$ and about $33 \mu \mathrm{g} \mathrm{mL}^{-1}$, respectively. These two fractions were subjected to a general separation procedure described in the experimental section. Compounds 1-3 were isolated from the $n-\mathrm{BuOH}$ extract and compound 4, with stigmasterol and oleic and linoleic acids, was isolated from the $n$-hexane extract. This paper deals with the structures and cell-growth-inhibitory activity of the compounds newly isolated from this plant (Fig. 1).

\section{Results and discussion}

Compound 1, colorless and amorphous, was assigned the molecular formula $\mathrm{C}_{22} \mathrm{H}_{28} \mathrm{O}_{8}$ by HR-FAB-MS [m/z 420.1764 (calcd for $\mathrm{C}_{22} \mathrm{H}_{28} \mathrm{O}_{8}, 420.1784$ )]. The ${ }^{13} \mathrm{C}$ NMR and DEPT spectra contained signals for tetra and penta-substituted benzene rings, four methoxy carbon atoms, and six $\mathrm{sp}^{3}$ carbons, two of which were $O$-substituted. This strongly suggested a lignan structure. The structure of $\mathbf{1}$ was determined from analysis of 2D NMR HMQC, HMBC, and COSY spectra. The planar structure of $\mathbf{1}$ was the same as that of (+)lyoniresinol, obtained as the deacetylated derivative from Gaultheria yunnanensis, with similar ${ }^{1} \mathrm{H}$ and ${ }^{13} \mathrm{C}$ NMR data [2]. $[\alpha]_{\mathrm{D}}$ for compound $1\left(\sim 0^{\circ}, \mathrm{MeOH}\right)$ differed from those for $(+)$-lyoniresinol $\left([\alpha]_{\mathrm{D}}+68^{\circ}\right.$, $\mathrm{MeOH}[2])$ and epilyoniresinol $\left([\alpha]_{\mathrm{D}}-28.9^{\circ}, \mathrm{MeOH}[3]\right)$ isolated from Grevillea robusta [3], however. In an NOEDF experiment, irradiation of $\mathrm{H}-7$ at $\delta 4.30(\mathrm{~d}$, $J=5.8 \mathrm{~Hz}$ ) revealed $\mathrm{NOE}$ in $\mathrm{H}-8$ at $\delta 1.93-1.98(\mathrm{~m})$ 
Fig. 1 Structures of compounds 1-4

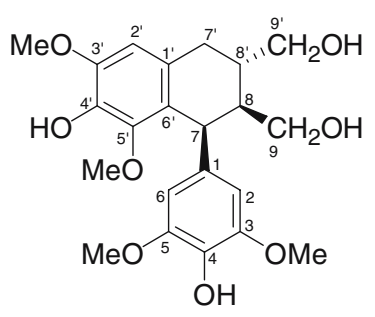

1 (relative)

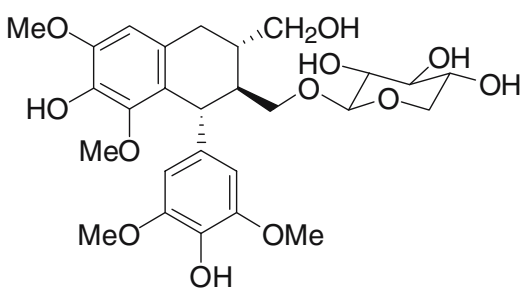

3<smiles>COc1cc([C@H]2c3c(cc(OC)c(O)c3OC)C[C@@H](CO)[C@H]2COC2OCC(O)CC(O)C2O)cc(O)c1O</smiles>

2

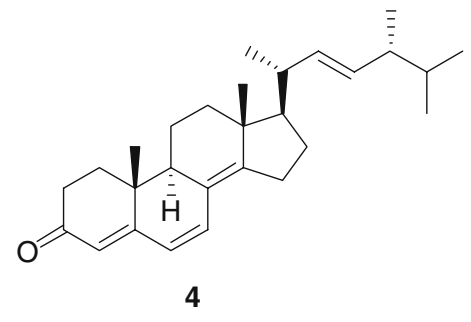

and Ha-9' at $\delta 3.48$ (dd, $J=7.3,10.8 \mathrm{~Hz}$ ), but not in $\mathrm{H}-8$ at $\delta 1.58-1.65(\mathrm{~m})$. A similar result was also obtained by irradiation of $\mathrm{H}-8$; NOE were observed in $\mathrm{H}-7$, $\mathrm{Ha}-9^{\prime}$, and $\mathrm{Hb}-9^{\prime}$ at $\delta 3.59$ (dd, $J=11.0,4.8 \mathrm{~Hz}$ ), which suggested the relative configuration of compound 1. The coupling constant of $\mathrm{H}-7 \quad(J=5.8 \mathrm{~Hz})$ was also indicative of cis orientation of $\mathrm{H}-7$ and $\mathrm{H}-8$. Compound 1 was a new lignan, and was named polystachyol.

Compounds $\mathbf{2}$ and $\mathbf{3}$ were initially isolated as a mixture, by use of reversed-phase HPLC with $\mathrm{MeOH}$-water (1:1) as mobile phase; they were, however, separated by use of a more polar mobile phase, $\mathrm{MeOH}$-water (2:3). Both had the molecular formula $\mathrm{C}_{27} \mathrm{H}_{36} \mathrm{O}_{12}$ and NMR spectra very similar to those of $\mathbf{1}$ with addition of a pentose sugar signals. Comparison of NMR and $[\alpha]_{D}$ data with published data enabled their identification as lyoniside and nudiposide, respectively $[4,5]$. Compounds 2 and 3 were diastereomeric xylosides of $(+)$ and $(-)$ lyoniresinol, respectively. This implied that compound $\mathbf{1}$ might be a racemate rather than a single enantiomer, because its $[\alpha]_{D}$ value was almost zero.

Compound 4, isolated from the $n$-hexane extract, was identified as ergosta-4,6,8(14),22-tetraen-3-one by comparison with published reference data [6], although assignment of C-24 ( $\delta 33.07)$ and C-25 $(\delta$ 42.86) and the corresponding protons $[\delta 1.45(\mathrm{~m}), \mathrm{H}-24$ and $\delta$ $1.83(\mathrm{~m}), \mathrm{H}-25]$ in the literature [6] should be interchanged, as was confirmed by HMBC and COSY analysis. Stigmasterol and oleic and linoleic acids were also identified by comparison with published reference data $[7,8]$.

Compounds 1-4, at maximum concentrations of $50 \mu \mathrm{g} \mathrm{mL}^{-1}$, were checked for growth-inhibitory activity against HeLa cells. None had positive activity, however. This suggested that material remaining after isolation of compounds 1-4 might contain the active principles.

\section{Experimental}

General experimental procedures

Optical rotation was measured with a Jasco P-1020 polarimeter. EI-MS, FAB-MS, and HR-MS were performed with Jeol GC-Mate, Jeol JMS-AX500, and Jeol HX-110A spectrometers, respectively. NMR spectra were acquired with Jeol A 500 and ECP600 spectrometers, with a deuterated solvent whose chemical shift was taken as an internal standard. Preparative HPLC was performed with a Waters $600 \mathrm{E}$ multisolvent delivery system connected to a Waters 486 tunable absorbance detector. Compounds were separated on a Senshu Pak ODS-5251-N column $(20 \mathrm{~mm} \times 250 \mathrm{~mm}$ i.d. $)$.

\section{Plant material}

The dried bark was collected from a traditional medicinal plant shop in Dhaka, Bangladesh, in September 2005. A voucher specimen was deposited in the Laboratory of Natural Products Chemistry, Graduate School of Pharmaceutical Sciences, Chiba University, Chiba, Japan.

\section{Extraction and isolation}

The dried bark of $A$. polystachya $(486.7 \mathrm{~g})$ was homogenized twice with a total of $1,900 \mathrm{~mL} \mathrm{MeOH}$ to obtain $25.0 \mathrm{~g}$ dried extract. The extract was suspended in $1,000 \mathrm{~mL} 10 \%$ aqueous $\mathrm{MeOH}$ and partitioned successively with $n$-hexane, EtOAc, and $n$-BuOH. Because the $n$-hexane and $n$ - $\mathrm{BuOH}$ extracts had maximum inhibitory effects, these two fractions were separated further. The 
$n$-BuOH extract (3.4 g) was first separated by Sephadex LH-20 column chromatography, with $\mathrm{MeOH}$ as mobile phase. One of these fractions $(223.8 \mathrm{mg})$ was then separated by column chromatography on silica gel $60 \mathrm{~N}$. The $\mathrm{CHCl}_{3}$-acetone (2:3 to $\left.1: 2\right)$ eluate $(14.9 \mathrm{mg})$ was separated by HPLC on an octadecylsilyl (ODS) column with $\mathrm{MeOH}$-water $(1: 1)$ as mobile phase to furnish compound $1(2.4 \mathrm{mg})$. The fraction $(179.3 \mathrm{mg})$ eluted from the silica gel column with $\mathrm{MeOH}$ was also applied to an ODS HPLC column with $\mathrm{MeOH}$-water (1:1) as mobile phase to yield a mixture of compounds which was further separated, by ODS HPLC with $\mathrm{MeOH}-$ water (2:3) as mobile phase, to furnish compounds 2 $(3.3 \mathrm{mg})$ and $3(3.3 \mathrm{mg})$.

The $n$-hexane extract $(1.73 \mathrm{~g})$ was first separated by Sephadex LH-20 column chromatography, with $\mathrm{CHCl}_{3}-$ $\mathrm{MeOH}(1: 1)$ as mobile phase, and the major fraction $(1.19 \mathrm{~g})$ was then applied to a silica gel (Wakogel C100) column. Two of the fractions eluted with $\mathrm{CHCl}_{3}$ yielded oleic acid $(13.8 \mathrm{mg})$ and linoleic acid $(1.2 \mathrm{mg})$. Stigmasterol $(60.9 \mathrm{mg})$ was obtained from the $\mathrm{CHCl}_{3}-$ EtOAc (5:1) eluates. One of the $\mathrm{CHCl}_{3}-$ EtOAc (10:1) eluates $(71.2 \mathrm{mg})$ was further separated by ODS column chromatography. The $\mathrm{MeOH}-\mathrm{CH}_{3} \mathrm{CN}$ (1:1 to 1:2) eluate $(6.2 \mathrm{mg})$ was purified by preparative silica gel TLC with $\mathrm{CHCl}_{3}-n$-hexane-EtOAc (5:5:0.4) as mobile phase to yield compound $4(2.0 \mathrm{mg})$.

\section{Polystachyol (1)}

Colorless, amorphous; $[\alpha]_{\mathrm{D}}^{22} \sim 0^{\circ}(c=1.0, \mathrm{MeOH})$; EI-MS $m / z(\%): 420\left(\mathrm{M}^{+}, 100\right), 402$ (14), 371 (18), 344 (4), 307 (7), 301 (6), 266 (6), 252 (28), 235 (16), 217 (30), 205 (33), 183 (38), 173 (19), 167 (36); HR-FAB-MS (NBA/PEG) $m / z 420.1764[\mathrm{M}]^{+}$(calcd for $\mathrm{C}_{22} \mathrm{H}_{28} \mathrm{O}_{8}, 420.1784$ ); ${ }^{1} \mathrm{H}$ NMR $\left(\mathrm{CD}_{3} \mathrm{OD}, 500 \mathrm{MHz}\right) \delta 1.58-1.65\left(1 \mathrm{H}, \mathrm{m}, \mathrm{H}-8^{\prime}\right)$, $1.93-1.98(1 \mathrm{H}, \mathrm{m}, \mathrm{H}-8), 2.57(1 \mathrm{H}, \mathrm{dd}, J=15.2,11.3 \mathrm{~Hz}$, Ha-7'), $2.69\left(1 \mathrm{H}, \mathrm{dd}, J=15.2,4.8 \mathrm{~Hz}, \mathrm{Hb}-7^{\prime}\right), 3.36(3 \mathrm{H}$, $\left.\mathrm{s}, 5^{\prime}-\mathrm{OCH}_{3}\right), 3.46-3.50(2 \mathrm{H}, \mathrm{m}, \mathrm{H}-9), 3.48(1 \mathrm{H}, \mathrm{dd}$, $\left.J=11.0,7.3 \mathrm{~Hz}, \mathrm{Ha}-9^{\prime}\right), 3.59(1 \mathrm{H}, \mathrm{dd}, J=11.0,4.8 \mathrm{~Hz}$, $\left.\mathrm{Hb}-9^{\prime}\right), 3.73\left(6 \mathrm{H}, \mathrm{s}, 3-\mathrm{OCH}_{3}, 5-\mathrm{OCH}_{3}\right), 3.85\left(3 \mathrm{H}, \mathrm{s}, 3^{\prime}-\right.$ $\left.\mathrm{OCH}_{3}\right), 4.30(1 \mathrm{H}, \mathrm{d}, J=5.8 \mathrm{~Hz}, \mathrm{H}-7), 6.37(2 \mathrm{H}, \mathrm{s}, \mathrm{H}-2$, $\mathrm{H}-6), 6.58\left(1 \mathrm{H}, \mathrm{s}, \mathrm{H}-2^{\prime}\right) ;{ }^{13} \mathrm{C}$ NMR $\left(\mathrm{CD}_{3} \mathrm{OD}, 125 \mathrm{MHz}\right)$ : $\delta 33.6\left(\mathrm{C}-7^{\prime}\right), 40.9\left(\mathrm{C}-8^{\prime}\right), 42.3(\mathrm{C}-7), 49.6(\mathrm{C}-8), 56.6\left(3^{\prime}-\right.$ $\left.\mathrm{OCH}_{3}\right), 56.7\left(3-\mathrm{OCH}_{3}, 5-\mathrm{OCH}_{3}\right), 60.1\left(5^{\prime}-\mathrm{OCH}_{3}\right), 64.1$ (C-9), 66.8 (C-9'), 106.8 (C-2, C-6), 107.8 (C-2'), 126.2 (C-6'), 130.2 (C-1'), 134.5 (C-4), 138.9 (C-4'), 139.3 (C-1), 149.0 (C-3, C-5), 147.7 (C-5'), 148.7 (C-3').
Cell growth inhibitory assay

HeLa cells were seeded on to 96-well microtitre plates, at $6 \times 10^{3}$ cells per well, and were pre-incubated for $24 \mathrm{~h}$ at $37^{\circ} \mathrm{C}$. The medium was replaced with fresh medium containing different concentrations of samples in DMSO (not exceeding $0.5 \%$ concentration). The cells were then incubated at $37^{\circ} \mathrm{C}$ for $24 \mathrm{~h}$. Medium containing the samples was then removed and cell proliferation was determined by fluorimetric microculture cytotoxicity assay (FMCA) [9] using a fluorescence plate reader. The ratio of living cells was determined as the fluorescence in sample wells expressed as a percentage of that in the control wells, and cell growth inhibitory activity was indicated as $\mathrm{IC}_{50}$ values. Mitomycin $\mathrm{C}$ was used as the positive control.

Acknowledgments This work was partly supported by a Grant-inAid from Tokyo Biochemical Research Foundation (TBRF), Japan.

\section{References}

1. Ghani A (2003) Medicinal plants of Bangladesh with chemical constituents and uses, 2nd edn. Asiatic Society of Bangladesh, Dhaka

2. Zhang Z, Guo D, Li C, Zheng J, Koike K, Jia Z, Nikaido T (1999) Gaultherins A and B, two lignans from Gaultheria yunnanensis. Phytochemistry 51:469-472

3. Varma M, Varma RS, Parthasarathy MR (1980) Minor phenolic constituents of Grevillea robusta and Hakea saligna. Zeitschrift fuer Naturforschung, C. J Biosci 35C:344-345

4. Dada G, Corbani A, Manitto P, Speranza G, Lunazzi L (1989) Lignan glycosides from the heartwood of European oak Quercus petraea. J Nat Prod 52:1327-1330

5. Inoshiri S, Sasaki M, Kohda H, Otsuka H, Yamasaki K (1987) Aromatic glycosides from Berchemia racemosa. Phytochemistry 26:2811-2814

6. Lee WY, Park Y, Ahn JK, Park SY, Lee HJ (2005) Cytotoxic activity of ergosta-4,6,8(14),22-tetraen-3-one from the sclerotia of Polyporus umbellatus. Bull Korean Chem Soc 26:1464-1466

7. Pouchert CJ, Behnke J (1993) The aldrich library of ${ }^{13} \mathrm{C}$ and ${ }^{1} \mathrm{H}$ FT NMR spectra, 1st edn, vol I. Aldrich, Milwaukee, Wisconsin

8. Pouchert C J, Behnke J (1993) The Aldrich Library of ${ }^{13} \mathrm{C}$ and ${ }^{1}$ H FT NMR spectra, 1st edn, vol III. Aldrich, Milwaukee, Wisconsin

9. Larsson R, Kristensen J, Sandberg C, Nygren P (1992) Laboratory determination of chemotherapeutic drug resistance in tumor cells from patients with leukemia, using a fluorimetric microculture cytotoxicity assay (FMCA). Int $\mathbf{J}$ Cancer 50:177185 